\title{
The Buddha's Pre-awakening Practices and Their Mindful Transformation
}

\author{
Bhikkhu Anālayo ${ }^{1}$ (i) \\ Accepted: 6 May 2021 / Published online: 7 July 2021 \\ (c) The Author(s) 2021
}

\begin{abstract}
In his quest for awakening, according to the traditional account the Buddha tried and discarded various ancient Indian practices as being not in themselves conducive to awakening. Nevertheless, closer inspection shows that key elements of these practices became part of the Buddhist path, a transformation that involves mindfulness in one way or another. In this way, fasting transforms into mindful eating, breath control into mindfulness of breathing, and a reformulation of an aspiration for annihilation of the self, apparently held by ancient Indian cultivators of the meditative sphere of neither-perception-nornon-perception, comes to be conjoined to the cultivation of mindfulness of the body. These transformations shed light on the importance and adaptability of mindfulness in early Buddhist soteriology.
\end{abstract}

Keywords Annihilationism; Breath control; Buddha's asceticism; Fasting; Immaterial Sphere; Neither-perception-nor-nonperception

A decisive difference between the Buddha and his fully awakened disciples is his discovery of the path to awakening (SN 22.58 and SĀ 75), which enabled him to teach others so that they may also reach total freedom from defilements. The early textual sources show that discovery to have been the final outcome of a prolonged quest, during which the Buddha-to-be explored various approaches that in the ancient Indian setting were believed to lead to liberation. Although in the course of his quest he came to discard several such approaches as not ultimately leading to the type of freedom he was seeking, he reportedly still made use of essential elements of these approaches when teaching his disciples, though in a form adjusted to his teaching of a middle path of practice. Such adjustments involve in particular the incorporation of mindfulness in one way or another. Surveying the transformations of such ancient Indian practices so as to become part of the Buddhist path to liberation can shed light on the potential and adaptability of mindfulness in early Buddhist thought.

\section{Bhikkhu Anālayo}

1 Barre Center for Buddhist Studies, 149 Lockwood Road, Barre, Massachusetts 01005, USA

\section{The Buddha's Quest for Awakening}

The early discourses do not present a comprehensive biography of the Buddha, a concern reflected only in later texts composed long after his demise. For this reason, information on the life of the Buddha has to be gleaned in bits and pieces from various early discourses, where such information tends to occur as part of an illustration of a particular doctrinal point. The teaching itself was evidently the main concern in the early period, in comparison to which the Buddha as an individual was accorded comparatively less importance.

Based on combining the bits of information obtainable through a comparative study of the early discourses (Anālayo 2017), the Buddha's quest for awakening can be summarized as follows: After going forth, the future Buddha pursued a meditative path related to cultivating mental tranquility. Having learned how to overcome obstructions to meditative absorption, he placed himself under the guidance of two ancient Indian teachers and eventually attained the immaterial spheres of nothingness and of neither-perception-nor-non-perception.

Dissatisfied with such lofty attainments, he changed his approach and engaged in asceticism. Closer inspection of the early sources shows that these were in particular forceful control of the mind, breath control, and fasting. The ascetic mode of approach also turned out to be fruitless, and it was only when he had given up asceticism and regained his 
bodily strength that he finally discovered the middle path of practice that led him to awakening.

In what according to tradition was his first public teaching, the Buddha set aside asceticism as one of the two extremes to be avoided in order to navigate this middle path successfully (Anālayo 2012 and 2013). Nevertheless, each of the three main ascetic practices mentioned above does have a counterpart in the practices that the early discourses report the Buddha teaching to his disciples.

\section{Fasting}

The last of the ascetic practices undertaken by the Buddha during his quest for awakening was a severe form of fasting, which reportedly reduced his body to a pitiable state of weakness and brought him close to death. From the viewpoint of his eventual achievement of awakening, such fasting is decidedly not the way to proceed. Nevertheless, the different codes of monastic discipline show that the Buddha made intermittent fasting obligatory for his monastic disciples (Pachow 1955, p. 141). This takes the form of abstaining from solid food during the period from noon to sunrise of the next day. Lay practitioners adopt the same type of intermittent fasting on special observance days. In other words, some abstention from partaking of food is recommendable, as long as it stays within the confines of the middle path and does not result in one of the two extremes to be avoided.

In addition to such adoption of intermittent fasting, a perhaps even more important dimension is the need to be mindful when eating. This comes up regularly in accounts of the gradual path of practice for those who have gone forth (Anālayo 2016), described under the heading of "knowing one's measure with food" (bhojane mattaññubhojane mātrajñah/食知止足/zas kyi tshod ni shes pa). In support of establishing the right attitude for knowing one's measure, a discourse in the Dìrgha-ägama offers the following similes to illustrate the commendable mindset toward food:

It is just as a person who applies medicine to an ulcer in order to heal the ulcer, not seeking to adorn themselves nicely, nor out of personal pride. Young brahmin, in the same way a monastic takes sufficient food to support the body, without harboring indulgence. Again, it is like lubricating [the axle of] a chariot, wishing to make it movable and usable, so as to use it to transport a load to some place. In the same way a monastic takes sufficient food to support the body, wishing it to serve for practicing the path.

(DĀ 20: 猶如有人以藥塗瘡, 趣使瘡差, 不求飾好, 不以自高. 摩納, 比丘如是, 食足支身, 不憎慢恣. 又 如膏車, 欲使通利, 以用運載, 有所至到. 比丘如是, 食足支身, 欲爲行道).
Although the Pāli parallel to this Dìrgha-ägama discourse does not have these similes, a comparable presentation can be found in another Pāli discourse of which otherwise no parallels are known:

Monastics, it is just like a person who anoints a wound just for the purpose of healing, or it is just like [a person who] greases an axle just for the purpose of transporting a load. In the same way, monastics, a monastic partakes of food with wise reflection.

(SN 35.198: seyyathā pi, bhikkhave, puriso vanam ālimpeyya yāvad eva ropanatthāya, seyyathā vā pana akkhạ̣ abbhañjeyya yāvad eva bhārassa nittharanatthāya. evam kho, bhikkhave, bhikkhu pațisaìkhā yoniso āhāraṃ āhāreti).

Similar to intermittent fasting, the need to know one's measure with food applies also to lay practitioners. An example in case is an instruction on mindful eating given to King Pasenadi to assist him in surmounting a tendency to overeat (Anālayo 2018):

People who are constantly mindful

Know their measure with the food they have gotten.

(SN 3.13: manujassa sadā satīmato, mattaṃ jānati laddhabhojane).

People should collect themselves with mindfulness, Knowing their measure with any food.

(SĀ 1150: 人當自繫念, 每食知節量).

People should constantly recollect themselves with mindfulness

That on getting food and drink they should know their measure.

$\left(S \bar{A}^{2} 73\right.$ : 夫人常當自憶念, 若得飲食應知量).

The formulation in this instruction makes explicit what would also be implicit in the instruction for monastics regarding the cultivation of knowing measure with one's food, illustrated with the examples of anointing a wound or greasing an axle, in that such a practice relies on mindfulness. In short, rather than opting for completely foregoing food, the key element becomes the presence of mindfulness when eating. This involves a shift in emphasis from exerting a physical form of control to the observational abilities and potential of mindfulness.

\section{Breath Control}

Before attempting a complete fast, the future Buddha had reportedly applied himself in various ways to breath control. In the case of this type of practice, the transformation effected by mindfulness is particularly remarkable. Rather than attempting to control the breath, the requirement becomes simply remaining mindfully 
present with the natural flow of breathing. As in the previous case, the key is a shift in emphasis from exerting a physical form of control to the abilities and potential of mindfulness. The instructions resulting from this shift of perspective inculcate a receptive observation, remaining aware of the inhalations and exhalations as they naturally occur in a way that gives emphasis to the open receptivity of mindfulness rather than being solely concerned with cultivating focused attention (Anālayo 2019a).

Out of altogether sixteen distinct steps of practice, outlined in the instructions for mindfulness of breathing, only the first two are concerned with the breath itself. The task with these first two steps is to discern the length of the breath as either long or short. The remaining fourteen steps instead require contemplating various aspects of the meditative experience while remaining aware of the natural flow of inhalations and exhalations. The progression evident in this way aligns with the four establishments of mindfulness. The first tetrad of the instructions on mindfulness of breathing corresponds to contemplation of the body, the second to contemplation of feeling tones, the third to contemplation of the mind, and the last brings in various insight perspectives that build on awareness of impermanence and thereby fulfills contemplation of dharmas. In this way, the breath as a meditation object comes to serve as the basis of a cultivation of all four establishments of mindfulness.

In the Pāli version of the relevant instructions, the shift from paying attention to the breath itself in the first two steps to other modes of contemplation finds reflection in the employment of distinct verb forms to designate each of the respective meditative tasks. For the first two steps the task is one of knowing (pājānati), whereas with the remainder of the steps the required activity is to train oneself (sikkhati).

Giustarini (2020, p. 116) argued, however, that there is no real difference between the practitioner's task first to know and then to train, assuming that the latter verb is used merely because the corresponding instructions employ future verb forms. This suggestion overlooks the fact that a description of the Buddha's own practice (SN 54.11) uses "he knows" throughout and thus also for all instances involving future verb forms. The next discourse in the same Pâli collection (SN 54.12) conveys the sense that, since the mental hindrances have been completely eradicated in the case of a fully awakened one, there is no longer a need to "train" (Anālayo 2019b, p. 197). For those who have not yet reached such total freedom from the hindrances, however, some training would still be required.

\section{Thought Control}

The first of the main ascetic practices undertaken by the Buddha-to-be involves an attempt to force unwholesome states out of the mind. This approach has found inclusion in a list of successive methods for overcoming unwholesome thoughts, given in the Vitakkasanthānasutta and its parallel. The actual practice described in the two discourses pertains to the realm of right effort. If unwholesome thoughts have been noticed with mindfulness but nevertheless persist, more active measures than just mindful watching need to be employed. The two discourses list five such methods (Catherine 2022). The first four can be summarized as recommending the following actions:

Direct attention to something wholesome.

Realize the danger of what is going on.

Just set aside the issue at hand.

Gradually relax the motivational force behind what is happening.

If each of these four methods has proven to be unsuccessful in making the mind emerge from unwholesome thought, the fifth method falls into place as what one should do:

With teeth clenched and the tongue pressed against the palate the mind should be restrained, subdued, and dominated through the mind.

(MN 20: dantehi dantamādhāya jivhāya tālum $\bar{a} h a c c a$ cetas $\bar{a}$ cittam abhiniggaṇhitabbam abhinippīletabbam abhisantāpetabbam).

With teeth clenched and the tongue pressed against the palate one should use the mind to fix the mind, taking hold of it and subduing it, so that bad and unwholesome thoughts no longer arise.

$(M A \bar{A}$ 101: 齒齒相著, 舌逼上䶖, 以心修心, 受持, 降 伏, 令不生惡不善之念).

The ability to use this method when it is indeed appropriate, rather than defaulting to it, requires monitoring with mindfulness. In the context of a cultivation of the eightfold path, the role of mindfulness in relation to other path factors is precisely to oversee their implementation (Anālayo 2020), which in the present context applies in particular to right effort. From this viewpoint, facing unwholesome thoughts requires a combination of effort with mindfulness. When things are about to get out of hand, when the unwholesome mental thoughts have become so obsessive as to risk precipitating unwholesome acts, the time has come to pull the emergency brake. This is what the passage translated above provides: an emergency brake. In itself, this will not lead forward on the path, just as pulling the emergency brake will not lead forward in a journey. For this reason, both are to be used with circumspection and only when really required in order to avoid an accident. Throughout, the task of mindfulness is to remain present and aware, thereby furnishing the information required to take proper action. 


\section{Annihilationism}

Before engaging in asceticism, the Buddha-to-be had developed the meditative attainments of the immaterial spheres of nothingness and neither-perception-nor-non-perception. The same two attainments feature regularly in the early discourses as part of a set of four immaterial spheres that can be cultivated by those who have gained mastery of the absorptions. Although the immaterial spheres are not indispensable for progress to awakening, they can provide support for such progress. Apart from such reframing of their importance, by clarifying that the immaterial spheres are certainly not the final goal, however, their actual practice has not really been transformed in a way comparable to the ascetic practices surveyed above. Their meditative cultivation as such necessarily involves some degree of mindfulness, without whose presence it would not be possible to access deeper levels of concentration (Anālayo 2019c).

Nevertheless, there is an instance of transformation evident in the present case as well. This concerns the aspiration apparently held by ancient Indian practitioners of the sphere of neither-perception-nor-non-perception, which a Pâli discourse reports in the following form:

Monastics, this is supreme among the views held by outsiders, namely: 'I might not be, and it might not be for me. I will not be, and it will not be for me.'

(AN 10.29: etad aggaṃ, bhikkhave, bāhirakānam dițțigatānaṃ yad idam no c' assaṃ no ca me siyā, na bhavissāmi na me bhavissat̄̄ ti).

Parallels to this Pāli passage extant in Chinese and Tibetan do not give the actual aspiration and instead identify attainers of the sphere of neither-perceptionnor-non-perception as holding the supreme among views held by those qualified as "outsiders," in the sense of not being members of the Buddhist tradition (MĀ 215: 非有想非無想處 and Up 5011: 'du shes med 'du shes med min skye mched). It seems fairly probable that these parallels intend the same as in the passage translated above, given that the relevant discourse quotation in the Abhidharmakośabhāṣya (V.19) reads similar to the Pāli formulation:

This was said by the Blessed One: 'This is supreme among the views held by outsiders, namely: 'I might not be, and it might not be for me. I will not be, and it will not be for me.'

(Pradhan 1967, p. 290: evoktam bhagavatā: etad agram bāhyakānām dṛ̦țigatānām yaduta no ca syām no ca me syāt, na bhavisyāmi na me bhavișyatì ti).

The Abhidharmakośabhāsya introduces this aspiration as an annihilationist view (ucchedadrști). A Pāli discourse reporting the same aspiration (SN 22.81) similarly qualifies it as an instance of annihilationism, a qualification confirmed by its counterparts in Chinese and Tibetan even though these, once again, do not give the content of the view (SĀ 57 and Up 2042; Anālayo 2014, p. 59 and Dhammadinnā 2014, p. 112).

The Brahmajāla-sutta and its parallels agree in presenting all of the four immaterial spheres under the heading of annihilationist views (Anālayo 2009, p. 213), indicating that those who identify a certain immaterial sphere as a self at the same time acknowledge the existence of another self that has been identified by adherents of a lower immaterial sphere. For example, proponents of the view that the self corresponds to the fourth immaterial sphere of neitherperception-nor-non-perception acknowledge that the third sphere of nothingness is also a type of self. Yet, according to their assessment the fourth sphere constitutes a subtler self of which the proponents of nothingness are not aware. This mode of presentation suggests the idea of increasingly subtler levels of the self that need to be identified in order to be transcended.

As already noted by Franke (1913, p. 37 note 1), the proposals of self-annihilation, surveyed in this part of the Brahmajāla-sutta and its parallels, can be understood from the viewpoint of self-notions based on perception, described in the Potțhapäda-sutta and its parallels:

Venerable sir, I assert the self to be immaterial and made of perception.

(DN 9: arūpiṃ kho ahaṃ, bhante, attānaṃ paccemi sañ̃̃ämayan ti).

Good Gautama, on designating the self of a person, I designate it as being immaterial and made of perception.

(Melzer 2006, p. 262, fragment v4: (arüp)i(nam a)ham bho gautama purușasya saṃjñämayam àtmānaṃ prajñ $<\bar{a}>$ payan prajñāpayāmi).

My own assertion is that the sphere of [infinite] space, the sphere of [infinite] consciousness, the sphere of nothingness, and the sphere of neither-perception-nornon-perception, that these immaterial realms are the self.

(DĀ 28: 我自說空處, 識處, 不用處, 有想無想處, 無 色天是我).

Bodhi (1978/1992, p. 30) reasoned that the position described in the Brahmajāla-sutta and its parallels would evidently

not regard annihilation as the ineluctable fate of all beings, but as the ultimate destiny and highest good of the spiritually perfected saint. They may be formula- 
tions of those mystical theologies which speak of the 'annihilation of the soul in God,' the 'descent into the divine abyss,' 'the merging of the drop into the divine ocean,' etc. as the supreme goal of their contemplative disciplines. On this interpretation, those beings who have not reached the summit will still be subject to continued existence, while those who reach the peak will attain the supreme good of annihilation in the divine essence.

In other words, the idea appears to have been that, with the successful cultivation of the immaterial spheres, a realization takes place that enables the practitioner to reach complete transcendence of selfhood at death. Hence, the aspiration "I might not be, and it might not be for me. I will not be, and it will not be for me." Understood in this way, the first sentence would be particularly pertinent to those aspiring to reach the meditative attainment, the second sentence instead for those who have mastered it and are thus, in their view, assured of successful annihilation at death.

The two parts of each half ("I might/it might" and "I will/ it will") could in turn be interpreted to refer to the annihilation of the self (qua perception of the respective immaterial sphere) and to the annihilation of the world experienced by this self during those times when not perceptive of the particular immaterial sphere. On this interpretation, the aspiration could be reformulated as follows: If I were to master the attainment of neither-perception-nor-non-perception, then at death the self might be annihilated, and the world experienced by the self might be annihilated. I have mastered the attainment of neither-perception-nor-non-perception, therefore at death the self will be annihilated, and the world experienced by the self will be annihilated.

Regarding the actual aspiration "I might not be, and it might not be for me. I will not be, and it will not be for me," Levman (2020, p. 62) took this formulation to be the result of an error in transmission that had as its origin "an old Vedic (pre-Buddhist) colloquialism, whose precise meaning is impossible to determine without context, but appears to have something to do with personal ownership." This suggestion comes without any evidence for the existence of such a colloquialism or for the actual occurrence of the supposed transmission error (two variations of which are given), which anyway would only explain the first half of the statement, not its second part. The main reason for this proposition appears to be that the author failed to understand how such a formulation could be an annihilationist view (p. 60): "It is unclear how this is an annihilationist view unless the statement is taken as denying any existence at all to the self, even conventionally." Yet, the views described in the Brahmajāla-sutta and its parallels are not about "denying any existence at all to the self." Much rather, they grant the existence of a self but wish to transcend it.
A related misunderstanding can be found in Westerhoff (2016, p. 368) who commented on the same view (as recorded in the Abhidharmakośabhāsya V.19) that the "non-Buddhist view referred to here is likely to be [the] position of the Cārvākas who deny the reality of future lives, and with it the working of karmic causality across lives." As clarified in the quote by Bodhi (1978/1992, p. 30) given above, the exposition related to the four immaterial spheres in the Brahmajāla-sutta and its parallels shows that this type of annihilationists did "not regard annihilation as the ineluctable fate of all beings, but as the ultimate destiny and highest good of the spiritually perfected saint" (italics added). That is, they grant the existence of a self that is bound to be reborn but wish to transcend such rebirth.

From the perspective of Buddhist thought, the very granting of a self as a transmigrating entity is the problem inherent in such annihilationist aspirations. This evaluation comes up explicitly in the Pañcattaya-sutta and its Tibetan parallel, which agree in highlighting that the attempt to annihilate the self is still in bondage to the very notion of a self (MN 102 and Skilling 1994, p. 344).

\section{A Reformulation}

The Buddhist transformation of what appears to have been an aspiration by ancient Indian annihilationists can be seen in the following inspired utterance (udāna), whose Pāli and Sanskrit versions are so closely similar as to allow rendering both with a single English translation (the Chinese parallels are too different to be of help here):

One in whom mindfulness of the body

Is continuously established in every respect

[Reflects]: 'It might not be, and it might not be for me.

It will not be, and it will not be for me,'

Dwelling thus successively,

One will in time transcend attachment.

(Ud 7.8: yassa siyā sabbadā sati

satatạ̣ kāyagatā upațthitā:

no c' assa no ca me siyā

na bhavissati na ca me bhavissati;

anupubbavihāri tattha so

kālen' eva tare visattikan ti).

(Uv 15.4: yasya syāt sarvatah smrtị

satatam kāyagatā hy upasthitā,

no ca syān no ca me syān

na bhavișati na ca me bhavișati,

anupūrvavihāravān asau

kālenottarate viṣaktikām).

The decisive reformulation of the annihilationist aspiration involves replacing "I might not be" with "it might not be" and "I will not be" with "it will not be." The main 
difference between the two formulations appears to be that, whereas the aim of the former is the annihilation of a self at the time of death, the latter points to a realization of the delusive nature of the very concept of a self and hence the relinquishing of all clinging related to self-notions (Anālayo 2021).

From this viewpoint, then, the shift of formulation to "it might not be" and "it will not be" expresses the insight that there is no substantial self to be overcome in the first place and what indeed needs to be annihilated, the "it," is clinging to any self-notion or form of conceit. The formulation "it might not be for me" and "it will not be for me" then serves to underline that the aspired goal can be reached when the individual, "me," is still alive. That the final goal can be reached while still alive, rather than being attained only at death, is indeed a major difference between ancient Indian notions related to the attainment of neither-perception-nor-non-perception and the early Buddhist conception of the final goal as something to be attained here and now.

On this interpretation, the Buddhist aspiration could be reformulated as follows: If I were to gain at least streamentry and thereby be ensured of progress to full awakening, then the conceit of a self might be annihilated, and all my clinging might be annihilated. I have gained streamentry (or once-return or non-return), so I am assured of progress to full awakening where the conceit of a self will be annihilated, and all my clinging will be annihilated.

The inspired utterance translated above relates the Buddhist mode of aspiration to mindfulness. Mindfulness of the body needs to be "continuously established in every respect." This is what, according to the Pāli and Sanskrit versions, forms the meditative foundation for implementing this reformulation of the annihilationist tenet. It is through embodied mindfulness that the proper foundation has been established for bringing to fruition the aspiration to annihilate all clinging and defilements.

In sum, the above survey shows how different practices, reportedly tried by the Buddha during his quest for awakening and found insufficient for leading to this goal, have been transformed and adapted to the cultivation of mindfulness as a key element in progress to awakening. In this way, fasting becomes replaced by mindful noting of one's measure when eating, breath control evolves into mindfulness of breathing, thought control becomes an emergency measure in a practice that involves predominantly mindful awareness of what happens in the mind, and a reformulated version of an aspiration for annihilation can have an embodied form of mindfulness as its meditative foundation.

Abbreviations AN: Añguttara-nikāya; DĀ: Dīrgha-āgama (T 1); DN: Dīgha-nikāya; MĀ: Madhyama-āgama (T 26); MN: Majjhimanikāya; SĀ: Samyukta-āgama (T 99); $\mathrm{SA}^{2}$ : Samyukta-āgama
(T 100); SN: Saṃyutta-nikāya; T: Taishō edition; Ud: Udāna; Up: Abhidharmakośopāyikā-ț̄ikā; Uv: Udānavarga

Funding Open Access funding enabled and organized by Projekt DEAL.

\section{Declarations}

Ethical Approval This article does not contain any studies performed by the author with human participants or animals.

Conflict of Interest The author declares he has no conflict of interest.

Open Access This article is licensed under a Creative Commons Attribution 4.0 International License, which permits use, sharing, adaptation, distribution and reproduction in any medium or format, as long as you give appropriate credit to the original author(s) and the source, provide a link to the Creative Commons licence, and indicate if changes were made. The images or other third party material in this article are included in the article's Creative Commons licence, unless indicated otherwise in a credit line to the material. If material is not included in the article's Creative Commons licence and your intended use is not permitted by statutory regulation or exceeds the permitted use, you will need to obtain permission directly from the copyright holder. To view a copy of this licence, visit http://creativecommons.org/licenses/by/4.0/.

\section{References}

Anālayo, Bh. (2009). Views and the Tathāgata: a comparative study and translation of the Brahmajāla in the Chinese Dīrgha-āgama. In Buddhist and Pali Studies in Honour of the Venerable Professor Kakkapalliye Anuruddha, K.L. Dhammajoti \& Y. Karunadasa (ed.), pp. 183-234. Hong Kong: Centre of Buddhist Studies, University of Hong Kong.

Anālayo, Bh. (2012). The Chinese parallels to the Dhammacakkappavattanasutta (1). Journal of the Oxford Centre for Buddhist Studies, 3, 12-46.

Anālayo, Bh. (2013). The Chinese parallels to the Dhammacakkappavattana-sutta (2). Journal of the Oxford Centre for Buddhist Studies, 5, 9-41.

Anālayo, Bh. (2014). On the five aggregates (4) - a translation of Samyukta-āgama discourses 33 to 58. Dharma Drum Journal of Buddhist Studies, 14, 1-71.

Anālayo, Bh. (2016). The gradual path of training in the Dīrgha-āgama, from sense-restraint to imperturbability. Indian International Journal of Buddhist Studies, 17, 1-24.

Anālayo, Bh. (2017). A meditator's life of the Buddha, based on the early discourses. Cambridge: Windhorse Publications.

Anālayo, Bh. (2018). Overeating and mindfulness in ancient India. Mindfulness, 9(5), 1648-1654. https://doi.org/10.1007/ s12671-018-1009-x.

Anālayo, Bh. (2019a). Meditation on the breath: mindfulness and focused attention. Mindfulness, 10(8), 1684-1691. https://doi. org/10.1007/s12671-019-01169-9.

Anālayo, Bh. (2019). Mindfulness of breathing: a practice guide and translations. Cambridge: Windhorse Publications.

Anālayo, Bh. (2019). The role of mindfulness in the cultivation of absorption. Mindfulness, 10(11), 2341-2351. https://doi.org/10. 1007/s12671-019-01206-7.

Anālayo, Bh. (2020). The qualities pertinent to awakening: bringing mindfulness home. Mindfulness. https://doi.org/10.1007/ s12671-020-01398-3. 
Anālayo, Bh. (2021). An inspired utterance on annihilation. Sri Lanka International Journal of Buddhist Studies 7.

Bodhi, Bh. (1978/1992). The all-embracing net of views, the Brahmajāla sutta and its commentaries, translated from the Pali. Kandy: Buddhist Publication Society.

Catherine, S. (2022). Beyond Distraction: Practical Ways to Free the Mind. Boston: Wisdom Publications.

Dhammadinnā, S. (2014). A translation of a discourse quotation in the Tibetan translation of the Mūlasarvāstivāda Vinaya parallel to Chinese Samyukta-āgama discourse 36 and of the discourse quotations in Śamathadeva's Abhidharmakośopāyikā-țīkā parallel to Chinese Samyukta-āgama discourses 39, 42, 45, 46, 55, 56, 57 and 58. Dharma Drum Journal of Buddhist Studies, 14, 73-128.

Franke, R. O. (1913). Dīghanikāya, das Buch der langen Texte des Buddhistischen Kanons, in Auswahl übersetzt. Göttingen: Vandenhoeck \& Ruprecht.
Giustarini, G. (2020). La pratica della consapevolezza: sati nel canone buddhista pali. Monterotondo: Fuorilinea.

Levman, B. G. (2020). Pāli, the language, the medium and message. Newcastle: Cambridge Scholars Publishing.

Melzer, G. (2006). Ein Abschnitt aus dem Dīrghāgama. PhD thesis. München: Ludwig-Maximilians-Universität.

Pachow, W. (1955). A comparative study of the prātimokșa, on the basis of its Chinese, Tibetan, Sanskrit and Pali versions. Santiniketan: Sino-Indian Cultural Society.

Pradhan, P. (1967). Abhidharmakośabhāsya of Vasubandhu. Patna: K.P. Jayaswal Research Institute.

Skilling, P. (1994). Mahāsūtras: great discourses of the Buddha. Oxford: Pali Text Society.

Westerhoff, J. (2016). On the nihilist interpretation of Madhyamaka. Journal of Indian Philosophy, 44, 337-376. https://doi.org/10. 1007/s10781-014-9266-z 